\title{
Hyper-activating Inukshuks: The renewal of social studies in Alberta
}

\author{
J-C Couture \\ Associate Co-ordinator, Government-Research \\ Alberta Teachers' Association \\ JC.Couture@ata.ab.ca
}

\section{Context}

A recent study that surveyed close to 500 Alberta social studies teachers concluded that irreconcilable pressures "point to tensions between the formal program of studies and its prescribed outcomes, and the realities and complexities of classrooms where teachers attempt to realize good practices" (Alberta Teachers' Association, 2016, p, 46). As the researchers observed, while there is widespread support for addressing "indigeneity" and "multiple perspectives," such expectations need to be contextualized in the experiences of the lived curriculum in classrooms where teachers are putting in 60-hour work weeks in the midst of ever increasing prescription and control over their practice (pp. 30-31).

Seven years ago, Education Minister David Hancock informed Albertans that the government's blueprint for "the transformation" of provincial K-12 education had achieved a number of key "milestones" (Alberta Education, 2011, p. 50). These included the publication of The Framework for Student Learning: Competencies for Engaged Thinkers and Ethical Citizens with an Entrepreneurial Spirit (Alberta Education, 2012) and The Learning Technology Framework (2013) to name a few documents that promised significant change in teaching and learning in Alberta.

As another milestone in Canadian public policy, the Truth and Reconciliation Commission (TRC) of Canada (2015) report created a political imperative and a sense of urgency for policy makers and educators. Immediately following their election, the Alberta New Democratic government unveiled an ambitious plan to infuse and embed indigeneity into the complex ecologies of Alberta's 2,000 classrooms through a redesign of the K-12 curriculum. Further fuelling the government's reform agenda, this past summer, an international report card on Indigenous education released in August 2017 (OECD, 2017) Promising Practices in Supporting Success for Indigenous Students further advanced the narrative of First nations as a collective body that continues to live in a policy space defined as an "achievement gap."

\section{Marking Milestones on the 'Indigeneity' Journey}

By unpacking the narratives of milestones and the linear march of curriculum policymaking, I sketch here why Alberta cannot make the mistake of assuming that reform will be a clear march forward where a western Enlightenment view of the world continues to frame Indigenous people as "failed versions of ourselves" (Davis in Grainger, 2009). Instead, we need to see "decolonization is as much a process as a goal (Harsha Walia in Kino-nda-niimi Collective, 2014, p. 45). As one teacher recently wryly shared at a curriculum workshop: 
I understand the proposed changes in direction for the new curriculum - which by the way I agree with - but after breaking open and scrambling the philosophical, cultural, and political eggs of the western worldview that drives what we teach and assess success, well, I ask myself, what kind of omelet, what do I serve on Monday morning in my class?

Millions (2014) identified the need to resist the unintended totalization of Indigenous peoples as a singular body politic that has been collectively traumatized. While the trauma of the residential schools is a critical historical reality - so too is the fact that since 2014 two-thirds of all First Nations communities in Canada had been under at least one drinking water advisory since 2004 and currently in Alberta 13 communities are subject to these same conditions (Hampshire, 2017). These predicaments, both philosophical and material, raise questions as to the ways we have configured educational progress through milestones - pursuing a linear policy path driven, at times, by the impulse to do the wrong things better.

A cursory review of Wikipedia quickly reminds us that milestones (Latin: Miliarium) were originally stone obelisks - often carefully crafted from granite, marble, or whatever local stone was available - to more modern times, with the industrial uniformity of cast concrete posts. Notably, many Roman milestones recorded the name of the reigning emperor without (conveniently for the colonizing Romans) consideration of the local names given to a place. Today the political impulse to signify empire and control carries over into the United States with the Zero Milestone in Washington, D.C., intended as the point from which all road distances in the United States are calculated. In these ways milestones represent the aspirations and anxieties of western societies forged at the intersections of power and control, identity and subjectivity, and how they signal our modernist settler culture of a particular relationship to space, time and place.

\section{The Future of Social Studies - Hyper-activating the Inukshuk?}

Juxtaposing the milestone as a marker for the human agency of journeying, the Inuksuk has a complex history with its multiple purposes on (now Canadian) land both as a navigational aid and a marker of rich localized histories of how to be a human here where they stand. Norman Hallendy (1992, p. 9) writes that:

Whether they symbolised their makers, acted in their capacity, or were the objects of veneration, inuksuit functioned as semaliths - messages created by the arrangements of stones. They were an integral part of the hunter's language, Inuksuit were reliable message centres.

In some beguiling ways the dual purposes of Inuksuit as "message centres" signalling where to be and how be on the land speaks to the promise and challenge we face here in Alberta's social studies curriculum redesign. In contrast to the linear narrative and imaginary of the RomanBritish milestone, the Inukshuk and the multiple ways it has become appropriated and colonized, speaks to our complex curriculum journey ahead—one perhaps more aptly described as bricolage, a process of tinkering and improvisation by mediating the materials of culture and memories constantly being lost and rediscovered (Deleuze \& Guattari, 2004, p. 7-8). 
We must avoid thinking of "indigeneity" as point of departure and a fixed thing frozen in time. Think of the Inuksuit that are no longer markers of the Inuit temporal landscape. In southern Ontario, tourist shops and Inuit art galleries are overwhelmed with inuksuit trinkets and other paraphernalia: inuksuit mouse pads, fridge magnets, and jewellery. Indeed, "adaptations of the inuksuk form are occupying many front gardens of suburban residences in Quebec City, Ottawa and Montreal — replacing the garden gnome and pink flamingo folly" (Heyes, 2002, p. 21). A controversy over an installation of three Inuksuk this past Fall at Pearson International airport further speaks to the challenge of building a curriculum where officials assume that "First Nations" and "multiple perspectives" can be seamlessly rolled into curriculum reform. As it turns out, a well-intended gesture of recognizing Inuit history was shaken by the concern by some Inuit that the Inukshuk's raised arms "designated as dangerous places to be avoided" (CBC News, 2017).

In a recent study comparing the very different approaches to curriculum renewal and Indigenous education in Alberta and New Zealand, our international research team shared their view that both our jurisdictions must considered both "truth" and "reconciliation" as ongoing iterative processes that cannot succeed by designing elaborate and complex curricular documents and externally imposed assessments (Couture et al, 2017, n.p.). Instead this work involves considering "curriculum as an encounter" where "indigenous perspectives cannot become just one more thing to do, one more learning outcome or milestone to mark and move past - along with computer coding, 21st century skills, gender and sexual identity, and francophone perspectives" (Couture et al, 2017; den Heyer, 2009).

As public debates over statues as placeholders of a particular and limited imago of Canadian-nes, we must be mindful to try and see curriculum markers such as "indigeneity" as both signals of where to be and how to be in the world. If we fail, the current attempt to renew the program of social studies runs the risk simply triggering more hyperactivity that morphs "truth" and "reconciliation" into mere lawn ornaments on the already crowded landscape of Alberta schools. Thinking of curriculum redesign aesthetically as a sort of bricolage that must avoid appropriation and recolonization offers an opportunity to avoid truth and reconciliation becoming hollowed-out mantras that serve little to advance meaningful change.

\section{References}

Alberta Education. (2011). Speak out-The year in review. Edmonton, Canada: Government of Alberta. Retrieved from http://www.speakout.alberta.ca/LinkClick.aspx? fileticket $=$ oEN1STKTYs4\%3D\&tabid=1 $\underline{08}$

Alberta Education. (2012). Framework for student learning: Competencies for engaged thinkers and ethical citizens with an entrepreneurial spirit. Edmonton, Canada: Alberta Education.

Alberta Education. (2013). Learning and technology policy framework. Edmonton, Canada: Alberta Education.

Alberta Education. (2016). Teacher quality standards draft. Retrieved from http://www.lethsd.ab.ca/documents/general/Teaching\%20Quality \%20Standard $\% 20$ \%20Draft $\% 202016 \% 2003 \% 2002 . p d f$ 
Alberta Government. (2016). Future Ready programs. Retrieved from: https://www.alberta.ca/future-ready-programs.aspx

Alberta Teachers' Association (2015). Renewing Alberta's promise: A great school for all. Edmonton, Canada: Barnett House.

Alberta Teachers' Association. 2017. The future of social studies in Alberta - The voices of Alberta teachers. Edmonton, Canada: Barnett House.

Alberta Teachers' Association. (2016). Indigenous education program launched. Retrieved from: https://www.teachers.ab.ca/Publications/ATA\%20News/Volume-51-2016-17/Number2/Pages/Indigenous-education-program.aspx

CBC News. (2016, October 18). Government wants kids to be 'future ready'. CBC News. Retrieved from http://www.cbc.ca/news/canada/edmonton/alberta-government-wantskids-to-be-future-ready-1.3810112

CBC News. (2017, September 27). Inukshuk art at Toronto's Pearson airport angers some Inuit in Nunavut. Retrieved from http://www.cbc.ca/news/canada/north/inukshuks-torontopearson-irniq-1.4308698

Couture, J-C, Stiles, J., Sellar, S., \& Thompson, G. (2017, November). School leadership and the empty horizon of global competence: The Alberta case of curriculum reform. Presentation to Australian Association for Research in Education, Canberra.

Deleuze, G., \& Guattari, F. (2004). Anti-Oedipus: Capitalism and schizophrenia. Trans. Robert Hurley, Mark Seem, and Helen R. Lane. London, England: Continuum.

den Heyer, K. (2009). Sticky points: Teacher educators re-examine their practice in light of a new Alberta social studies program and its inclusion of Aboriginal perspectives. Teaching Education, 20(4), 343-355. doi:10.1080/10476210903254083

French, J. (2016, June 16). Ambitious Alberta education curriculum overhaul will cover climate change, gender diversity and Indigenous history. $C B C$ News. Retrieved from http://edmontonjournal.com/news/local-news/alberta-to-spend-64-million-to-overhauleducation-curriculum

Grainger, J. (2009, December 22). Language matters: An interview with Wade Davis. Retrieve from http://theexcerpt.com/2009/12/language-matters-part-one-of-an-interview-withwade-davis/

Hallenday, N. (1992). Inuksuit: Semalithic figures constructed in the Canadian arctic, Paper presented at the 25th Annual Meeting of the Canadian Archaeological Association, London, Ontario.

Hampshire, G. (2017, March 17). First Nations in Alberta 'encouraged' province will spend $\$ 100 M$ on safe drinking water. CBC News. Retrieved from http://www.cbc.ca/news/canada/edmonton/first-nations-in-alberta-encouraged-provincewill-spend-100m-on-safe-drinking-water-1.4030193

Heyes, S. (2002). Protecting the authenticity and integrity of inuksuit within the arctic milieu Érudit, 26(2), 133-156. Retrieve from http://id.erudit.org/iderudit/007648ar

King, T. (1990). All my relations. Toronto, Canada: McClelland.

Kino-nda-niimi Collective. (2014). The winter we danced. Winnipeg, Canada: Arbeiter Ring.

Million, D. (2014). Therapeutic nations: Healing in an age of Indigenous human rights. Tucson, AZ: University of Arizona Press.

OECD [OECD Education]. (2017). Promising practices in supporting success for Indigenous students [Tweet]. Retrieved from https://twitter.com/OECDEduSkills/status/895283811533115392

Turner, D. (2012). This is not a peace pipe. Toronto, Canada: University of Toronto Press. 